\title{
SOSIAALI- JA TERAPIATYÖN UUDELLEEN ORGANISOITUVA SUHDE - RAJAPINNOILTA KOHTI POTENTIAALISIA YHDYSPINTOJA ${ }^{1}$
}

\author{
Leena Leinonen: YTT, tutkijatobtori, Itä-Suomen yliopisto
}

leena.leinonen@uef.fi

Janus vol. 29 (3) 2021, 292-296

Mielenterveyden ja sosiaalisten tekijöiden välillä on vahva kaksisuuntainen yhteys. Sosiaalisen hyvinvoinnin murtumat, kuten työttömyys, yksinäisyys ja päihderiippuvuus, kuormittavat yksilön psyykeä ja altistavat erilaisille mielenterveyden ongelmille. Vastaavasti mielenterveysongelmat usein eristävät yksilön sosiaalisista suhteista ja yhteiskunnallisesta toimijuudesta ja aiheuttavat näin ulkopuolisuuden ja osattomuuden kokemuksia (Charles \& Bentley 2016). Mielenterveys on vahvasti kokemuksellinen konstruktio ja vaatii siksi toteutuakseen riittäviä sosiaalisia ja elämäntaidollisia mahdollisuuksia. Mielenterveysongelmien hoito ja kuntoutus pohjautuvat moniammatilliseen työskentelyotteeseen, jossa asiakkaan toimintakyvyn vajeita ja elämäntilannetta tarkastellaan ideaalitilanteessa niin psyykkisestä, fyysisestä kuin sosiaalisestakin näkökulmasta - myös yksilön elämänhistoriaan kiinnittyvä ajallinen näkökulma huomioiden. Kokonaisvaltaisen kuntoutuksen ihanteen mukaisesti mielenterveysongelmien hoitoon osallistuu pitkälle kehittyneissä psykiatrisissa konteksteissa sekä varsinaisen hoidon että erityisalojen ammattilaisia, joista yhden ryhmän muodostavat sosiaalityöntekijät.

Psykiatrisessa erikoissairaanhoidossa työn lähtökohta on aina hoidollinen. Voidakseen osallistua täysipainoisesti mielenterveyspotilaiden hoito- ja kuntoutusprosesseihin, myös sosiaalityöntekijöiden on tärkeää ymmärtää kattavasti mielenterveysongelmien luonnetta ja erilaisia hoitomuotoja. Kullekin mielenterveyden häiriölle tyypilliset oireet, niiden tuottamat toimintakyvyn rajoitteet sekä sairauden hoidossa käytetyt terapeuttiset interventiot, mukaan lukien psyykelääkitys, vaikuttavat olennaisesti potilaan arkielämään ja sosiaaliseen selviytymiseen. Mielenterveyskuntoutujan koko maailmasuhde määrittyy osin sairauden värittämänä Tästä näkökulmasta ei ole yllättävää, että osa psykiatrisista sosiaalityöntekijöistä on halunnut lisätä mielenterveystyön osaamistaan kouluttautumalla Sosiaali- ja terveydenhuollon lupa- ja valvontavirasto Valviran laillistamiksi terapeuteiksi ja toimii työssään kahdessa erilaisessa ammatillisessa roolissa, sekä sosiaalityöntekijänä että terapeuttina. Sosiaali- ja terapiatyöllä on paljon yhtymäkohtia, perustuvathan molemmat työmuodot inhimilliseen vuorovaikutukseen ja pyrkimykseen lisätä asiakkaan hyvinvointia (ks. esim. Kotkavirta 2008; Rauhala 2014). Sosiaali- ja terapiatyön peruslähtökohdat ovat kuitenkin erilaiset. Psykoterapia on ensisijaisesti psykologiseen teoriaan perustuva hoitomuoto, kun taas sosiaalityö on useista erilaisista interventioista koostuva, laaja-alainen tukimuoto. 
Terapeutin koulutus ja psykiatrisissa toimintakonteksteissa yleisesti sovellettu työn terapeuttinen viitekehys voivat vaikuttaa psykiatristen sosiaalityöntekijöiden ammatilliseen itseymmärrykseen sekä tietoisesti että tiedostamattomasti. Hoidollisissa organisaatioissa toimivat sosiaalityöntekijät voivat verrattain helposti mukautua yleisen terapeuttisen työn valtavirtaan, jolloin heidän ammattiroolinsa on vaarassa hämärtyä ja työn sosiaalinen perustehtävä voi ohentua (ks. esim. Antikainen-Juntunen 2005; Mullaly 1997). Ammattiroolin hämärtyminen on ongelmallista myös siksi, että sosiaalityöntekijöiden määrä suhteessa terveydenhuollon perinteisiin ammattikuntiin on varsin pieni. Siitä, mitä sosiaalityöntekijät tekevät sosiaalityö-nimikkeen alla ja kuinka he sitä tekevät, tulee sosiaalityötä kyseisessä toimintaympäristössä.Yksikön mahdollisesti ainoan sosiaalityöntekijän työnkuva moniammatillisessa yhteistyössä johtaa usein henkilöitymiseen, joka voi helposti määrittää muiden ammattikuntien näkemyksiä koko sosiaalityön funktiosta psykiatriassa (Mönkkönen ym. 2019).

Väitöstutkimukseni (Leinonen 2020) tavoitteena oli muodostaa kokonaiskuva ja ymmärrys siitä, millaisia merkityksï sosiaalityön terapeuttiseen orientaatioon liittyy osana psykiatrisen sosiaalityön ammatillisen itseymmärryksen rakentumista. Aihetta ei ole aiemmin tutkittu suomalaisessa kontekstissa ja hyvin vähän myös kansainvälisesti. Psykiatristen sosiaalityöntekijöiden terapiasuuntautuneisuus on näyttäytynyt virallisten tehtäväluokitusten ja sosiaalityöntekijöiden käytäntöperustaisten kokemusten valossa osin ristiriitaisena ilmiönä; mikä oikeastaan on sosiaalityön tehtävä psykiatriassa ja millainen merkitys terapeuttisuudella on mielenterveyssosiaalityön käytännössä? Määrittelen 'terapeuttisuuden' vuorovaikutuksessa tapahtuvaksi, asiakkaan psyykkis-fyysis-sosiaalisen tilan huomioivaksi tukemiseksi, jolla tavoitellaan asiakkaan kokonaisvaltaisen toimintakyvyn aktivoitumista tavalla, joka mahdollistaa ongelmanratkaisun ja elämänhallinnan.

Mielenterveystyön tutkimus on yhteiskunnallisesti tärkeää aikana, jona erilaiset mielenterveydelliset ongelmat ovat nousseet suurimmaksi yksittäiseksi suomalaisväestön pitkäaikaista työkyvyttömyyttä ja varhaista eläköitymistä aiheuttavaksi sairausryhmäksi. Vuonna 2019 mielenterveysongelmat olivat työkyvyttömyyseläkkeen taustalla 43 prosentissa eläkepäätöksiä (Findikaattori 2019). Mielenterveyspalvelujen käyttöaste on korkea ja kroonistuneesta psyykkisestä oireilusta koituvat yhteiskunnalliset kustannusvaikutukset ovat huomattavat. Käytössä olevat psykiatriset resurssit on tärkeää mobilisoida mahdollisimman hyvin, kaikkien mielenterveystyön ammattilaisten erityisosaamista maksimaalisesti hyödyntäen.

Tutkimukseni on monimenetelmäinen. Aineistoni koostuu psykiatrisen erikoissairaanhoidon sosiaalityöntekijöille suunnatusta valtakunnallisesta kyselystä, johon vastasi 249 sosiaalityöntekijää. Kyselyaineisto jakautui määrälliseen ja laadulliseen osaan. Syventääkseni ymmärrystäni tutkimuskohteestani haastattelin kyselyn jälkeen kahdeksan terapiakoulutettua sosiaalityöntekijää, jotka toimivat sekä sosiaalityöntekijänä että terapeuttina. Tarkastelen määrällisiä ja 
laadullisia aineistojani integroituna kokonaisuutena.

Tutkimukseni tulokset osoittavat, että aineiston keruuhetkellä 31 prosentilla vastanneista psykiatrisista sosiaalityöntekijöistä oli yksi tai useampi laillistetun terapeutin pätevyys. Lisäksi lähes 48 prosenttia vastaajista oli suorittanut vähintään yhden koulutuksen, joka antoi valmiuksia yksilökohtaiseen mielenterveystyöhön, muttei kuitenkaan tuottanut varsinaista terapiapätevyyttä. Tulosteni nojalla mielenterveyssosiaalityön terapeuttinen orientaatio on siis paitsi todellinen ilmiö, myös tekijä, joka vaikuttaa olennaisesti sosiaalityön ammatillisen itseymmärryksen rakentumiseen. Äärimuodoissaan psykiatriset sosiaalityöntekijät voivat hahmottaa työnsä terapeuttiseksi hoitotyöksi, jossa asiakkaan sosiaalisen hyvinvoinnin kysymykset jäävät työskentelyn ulkopuolelle, tai vastaavasti sosiaaliturvaohjaukseen ja -neuvontaan perustuvaksi tukityöksi, jossa asiakkaan mielenterveydellisiä kysymyksiä ei juuri huomioida.

Psykiatristen sosiaalityöntekijöiden yleisin terapiasuuntaus on tutkimukseni mukaan perheterapia, ja lastenja nuorisopsykiatria ovat psykiatrian erikoisalat, joilla terapiakoulutettuja sosiaalityöntekijöitä on eniten. Näillä erikoisaloilla sosiaalityöntekijöiden perheterapiasuuntautuneisuus on varsin luonnollinen ilmiö - ovathan alaikäiset yksilönkehityksessään vaiheessa, jossa perheen sisäinen vuorovaikutus on kasvun ja kehityksen näkökulmasta keskeistä. Lapsen tai nuoren kokonaisvaltainen psykiatrinen hoito ja kuntoutus edellyttävät sekä yksilön että hänen lähiyhteisönsä tukemista tavalla, joka kykenee tunnistamaan ja tunnustamaan perhedynamiikkaan kiinnittyvät moniulotteiset, psyykkistä hyvinvointia tukevat tai murentavat tekijät. Yksilönäkökulman ylittävä lähestymistapa myös huomioi enemmän asiakkaan arkielämän sosiaalisia reunaehtoja kuin yksilökeskeiset terapiasuuntaukset.

Tutkimukseni osoittaa, että keskeinen elementti terapeuttisuuden näkökulmasta on mielenterveyskuntoutujan toivon ja tulevaisuususkon herättely ja tukeminen. Mielenterveydelliset ongelmat ovat usein pitkäkestoisia, ja psyykkisesti sairaan elämä on sairauden suhteen parempien ja huonompien kausien vaihteluista koostuva jatkumo. Mielenterveyskuntoutujat joutuvatkin usein hyväksymään sairauden pysyväksi osaksi elämäänsä ja luomaan identiteettiään tämän tiedostaen. (Clossey \& Rowlett 2008; Spearman 2005.) Terapeuttisuus sosiaalityössä kulminoituu kuntoutujan aineellisen ja psyykkisen tukemisen rajapinnassa; konkreettisen ja emotionaalisen tuen elementtejä tapauskohtaisesti yhdistelevässä työotteessa. Konkreettiset asiakkaan elämäntilanteeseen kiinnittyvät interventiot, kuten sosiaaliturvaetuuksien hakeminen ja asumisohjaus eheyttävät asiakasta myös psyykkisesti, mikä puolestaan vahvistaa tunnetta elämänhallinnasta ja lisää siten yksilön kokonaisvaltaista hyvinvoinnin kokemusta - tästä käytän nimitystä yleisterapeuttisuus. Psyykkisen sairauden kokonaisvaltaisen luonteen tunnistava, yleisterapeuttinen kohtaaminen vie asiakasvuorovaikutusta hoidolliseen suuntaan, mikä on luontevaa koko toimintaympäristön ollessa hoidollinen. Yleisterapeuttinen asiantuntijuus ei edellytä laillistetun terapeutin koulutusta, mutta se vaatii 
toteutuakseen, että sosiaalityöntekijä huomioi aktiivisesti asiakkaan psyykkistä tilaa ja tunnistaa ja tunnustaa sen muotoutumiseen vaikuttavat moniulotteiset tekijät työskentelyn kaikissa vaiheissa. Tämän osaamisen merkitys on tärkeää huomioida jo sosiaalityön peruskoulutuksessa.

Tutkimukseni perusteella psykiatrisen sosiaalityön rakenteellinen työote kaipaa vahvistamista. Puolet kyselyyni vastanneista sosiaalityöntekijöistä koki, ettei heidän työhönsä sisälly lainkaan rakenteellista vaikuttamista. Tulos on huolestuttava sosiaalityön yhteiskunnallisen muutostyön perustehtävän näkökulmasta. Rakenteellisen työotteen vahvistamistarpeen tiedostaminen on tärkeää ennakoitaessa sosiaali- ja terveydenhuollon palvelurakenneuudistusta, jonka alkuperäisinä tavoitteina ovat olleet muun muassa palvelujen yhdenvertaistaminen ja väestöryhmien välisten terveyserojen kaventaminen. Tällöin on ensiarvoisen tärkeää huolehtia mielenterveyden sosiaalisten determinanttien näkyväksi tekemisestä, niitä aktiivisesti sanoittamalla.

Laillistetuista psykoterapeuteista on valtakunnallista pulaa. Myös vallitseva koronapandemia vaikuttaa mielenterveyspalveluiden järjestämiseen. Pandemian vuoksi osa psykiatrisen avohoidon toimipisteistä on väliaikaisesti suljettu, minkä vuoksi lähitulevaisuudessa on ennakoitavissa psykiatristen palvelujen ruuhkautumista. Suunnattaessa katse kohti SOTE-uudistusta ja koronapandemian jälkihuoltoa, yhtenä keskeisenä kysymyksenä on, kuinka suomalaisväestön mielenterveyspalvelujen tarpeeseen kyetään vastaamaan aiempaa aika- ja kustannustehokkaam- min. Sosiaali- ja terapiatyön yhdyspintojen tarkastelu voi tarjota tähän uusia ratkaisumalleja. Suomalaisessa lastensuojelutyössä on viime vuosien aikana sisäänajettu systeemistä työtapaa, jossa keskeisenä tahona toimii perheterapeutin pätevyyden omaava ammattilainen, josta käytetään nimitystä kliinikko. Kliinikko voi olla taustaltaan myös sosiaalityöntekijä. Työotteesta saadut alustavat kokemukset ovat rohkaisevia, mikä synnyttää osaltaan perustellun kysymyksen siitä, olisiko esimerkiksi systeemistä työotetta mielekästä jalkauttaa laajemmallekin sosiaali- ja terveyspalveluihin, mukaan lukien matalan kynnyksen mielenterveyspalvelut.

Mielenterveyskuntoutujan kokemusten aito huomioiminen edellyttää hoitoon ja kuntoutukseen osallistuvilta ammattilaisilta niin halua kuin myös kykyä ymmärtää sairauden merkitystä yksilön arkielämän näkökulmasta. Tutkimukseni nojalla psykiatrisessa sosiaalityössä on tärkeää ylläpitää yleisterapeuttista työorientaatiota. Se tekee näkyväksi sosiaalisten tekijöiden ja mielenterveyden välisen kaksisuuntaisen yhteyden ja samalla sitoo sosiaalityön toiminnallisen osajärjestelmän kiinteäksi osaksi moniammatillisesti rakentuvia hoito- ja kuntoutusprosesseja. Vaikka palvelurakenteet muuttuisivatkin, psykiatria hyötyy myös tulevaisuudessa sosiaalityön erityisasiantuntemuksesta.

\section{VIITE}

1 Puheenvuoro on Itä-Suomen yliopistossa 29.8.2020 tarkastetun sosiaalityön väitöskirjan lectio praecursoria. 


\section{KIRJALlisuUs}

Antikainen-Juntunen, Eija (2005) Sosiaalityö psykiatrisessa työkyvyn arvioinnissa. Sosiaalityöntekijöiden käsitysten arviointi empowermentin näkökulmasta. Sosiaalityön ammatillinen lisensiaatintutkimus. Kuntouttavan sosiaalityön erikoisala. Tampereen yliopisto, sosiaalipolitiikan ja sosiaalityön laitos. https://trepo.tuni. fi/bitstream/handle/10024/76407/lisuri00035. pdf? sequence $=1$ \&isAllowed $=y$ Luettu 20.8.2020.

Charles, Jennifer L. K. \& Bentley, Kia J. (2016) Stigma as organizing framework for understanding the early history of community mental health and psychiatric social work. Social Work in Mental Health 14 (2), 149-173. https://doi.org/ 10.1080/15332985.2014.964448

Clossey, Laurene \& Rowley, Al (2008) Effective organizational transformation in psychiatric rehabilitation and recovery Journal of Social Work in Disability and Rehabilitation 7 (3-4), 315-339. https:// doi.org/10.1080/15367100802487614

Findikaattori (2019) Työkyvyttömyyseläkettä saaneet. https://findikaattori.fi/ fi/76 Luettu 20.8.2020.

Kotkavirta, Jussi (2008) Psykoanalyyttinen teoria ja hyvän elämän kysymykset. Teoksessa Petteri Niemi \& Tuija Kotiranta (toim.) Sosiaalialan normatiivinen perusta. Helsinki: Gaudeamus, 240-277.
Leinonen, Leena (2020) Sosiaalityön ja terapian rajapinnalla. Sosiaalityön terapeuttinen orientaatio ja ammatillinen itseymmärrys psykiatrisessa erikoissairaanhoidossa. Publications of the University of Eastern Finland. Dissertations in Social Sciences and Business Studies 227. Kuopio: Itä-Suomen yliopisto.

Mullaly, Bob (1997) Structural social work. Canada: Oxford University Press.

Mönkkönen, Kaarina \& Leinonen, Leena \& Arajärvi, Miina \& Hovatta, Anna-Elina \& Tusa, Niina \& Salokangas, Katri (2019) Moniammatillisen vuorovaikutuksen tarkastelua. Teoksessa Kaarina Mönkkönen, Taru Kekoni \& Aini Pehkonen (toim.) Moniammatillinen vuorovaikutus sosiaali- ja terveysalalla. Helsinki: Gaudeamus, 47-88.

Rauhala, Lauri (2014) Ihmiskäsitys ihmistyössä. Helsinki: Gaudeamus.

Spearman, Len (2005) A developmental approach to social work practice in mental health: building on strenghts. Teoksessa Tuula Heinonen \& Anna Metteri (toim.) Social work in health and mental health: issues, developments and actions. Toronto: Canadian scholar's press Inc., 45-64. 